\title{
Pathogenesis and treatment of hypertension in haemodialysis patients with chronic kidney disease
}

\author{
Patogeneza i leczenie nadciśnienia tętniczego \\ u hemodializowanych chorych z przewlekłą chorobą nerek
}

\author{
Patrycja Pokora, Marcin Adamczak, Andrzej Więcek \\ Department of Nephrology, Transplantation and Internal Medicine; Medical University of Silesia, Katowice, Poland
}

\begin{abstract}
Hypertension is frequently diagnosed among patients with chronic kidney disease (CKD) and often remains poorly controlled in end stage kidney disease (ESKD) especially in haemodialysis patients. These patients are characterized by higher blood pressure variability than the general population. Volume overload is a primary factor contributing into the pathogenesis of hypertension in this cohort. In the diagnosis and monitoring of hypertension in haemodialysis patients with chronic kidney disease self-measured of blood pressure at home done during the days between haemodialysis sessions should be considered. Home blood pressure measurements are of greater prognostic value than haemodialysis unit recording. Target-values of blood pressure in haemodialysis patients are still matter of debate. However, self-measured systolic blood pressure values at home between 120 to $130 \mathrm{mmHg}$ are associated with the best prognosis in haemodialysis patients with CKD. Among not pharmacological methods of antihypertensive treatment in haemodialysis patients with CKD reducing volaemia by increasing ultrafiltration during haemodialysis procedures, individualization of sodium concentration in the dialysis fluid and low sodium diet should be listed. While, in the pharmacotherapy $\beta$-adrenergic antagonists seem to be the drugs of first choice.
\end{abstract}

Key words: hypertension, haemodialysis, chronic kidney disease

Arterial Hypertens. 2017, vol. 21, no. 4, pages: 195-204

Streszczenie

DOI: 10.5603/AH.a2017.0021

U chorych z przewlekłą chorobą nerek (PChN) często występuje nadciśnienie tętnicze. U wielu chorych z PChN leczenie nadciśnienia tętniczego nie jest w pełni skuteczne. Dotyczy to szczególnie chorych ze schyłkową niewydolnością nerek leczonych hemodializami. Chorzy ci charakteryzują się również większą zmiennością ciśnienia tętniczego niż populacja ogólna. Głównym czynnikiem w patogenezie nadciśnienia tętniczego u chorych ze schyłkową niewydolnością nerek leczonych hemodializami jest hiperwolemia. W rozpoznawaniu i monitorowaniu nadciśnienia tętniczego u tych chorych należy preferować wykonywanie samodzielnych domowych pomiarów ciśnienia tętniczego w dniach bez zabiegów hemodializy. Domowe pomiary ciśnienia tętniczego mają większą wartość prognostyczną niż pomiary ciśnienia tętniczego wykonywane w stacji dializ. Docelowe wartości ciśnienia tętniczego u chorych ze schyłkową niewydolnością nerek leczonych hemodializami są nadal przedmiotem kontrowersji. Wykazano jednak, że najlepszym rokowaniem charakteryzują się chorzy ze skurczowym ciśnieniem tętniczym wynoszącym w samodzielnych domowych pomiarach 120-130 mm Hg. Niefarmakologicznymi metodami leczenia przeciwnadciśnieniowego

Address for correspondence: Prof. Andrzej Więcek

Department of Nephrology, Transplantation and Internal Medicine

Medical University of Silesia, ul. Francuska 20/24, 40-027 Katowice, Poland

e-mail: awiecek@sum.edu.pl, tel.: (+48-32) 255-26-95, fax.: (+48 32) 255-37-26

VM Copyright (C) 2017 Via Medica, ISSN 2449-6170 
u chorych ze schyłkową niewydolnością nerek leczonych hemodializami są: zmniejszenie wolemii przez zwiększenie ultrafiltracji w trakcie hemodializy, indywidualizacja stężenia sodu w płynie dializacyjnym oraz zmniejszenie zawartości sodu w diecie. W farmakoterapii lekami pierwszego wyboru są antagoniści receptorów $\beta$-adrenergicznych. Słowa kluczowe: nadciśnienie tętnicze, hemodializa, przewlekła choroba nerek

Arterial Hypertens. 2017, vol. 21, no. 4, pages: 195-204

DOI: 10.5603/AH.a2017.0021

\section{Introduction}

Hypertension is highly prevalent in patients with chronic kidney disease $(\mathrm{CKD})$, particularly in patients with end-stage kidney disease (ESKD) treated with haemodialysis $[1,2]$ and it is the important risk factor contributing to the high cardiovascular morbidity and mortality in this population [3, 4]. In the early years of renal replacement therapy with haemodialysis, hypertension requiring pharmacologic therapy was seen only in $10 \%$ to $15 \%$ of the patients, most probably due to strict patients' selection, dialysate and dietary sodium restriction, attention to dry-weight and longer time of haemodialysis sessions [5]. However, more recent data suggest that the prevalence of hypertension in patients on chronic haemodialysis exceeds the number seen in the general population [6] or those with CKD not required haemodialysis [7]. Although, nowadays hypertension is present in $50 \%$ to $90 \%$ of patients on haemodialysis [8-10], it remains a controversial prognostic marker in patients with CKD stage 5 . In patients receiving chronic haemodialysis, approximately $45 \%$ of overall mortality is attributable to the cardiac disease. Acute complications of coronary heart disease in patients with renal dysfunction account only $20 \%$ of cardiac deaths [11]. In these patients cardiovascular diseases are more likely to manifest as calcification of the coronary arteries media $[12,13]$, left ventricular hypertrophy [14, 15], and sudden cardiac death [16]. In contrast to the guidelines for the general population, in which systolic blood pressure of $\leq 140 \mathrm{mmHg}$ is considered the treatment target, a debate remains regarding the target blood pressure in haemodialysis patients [17]. Hypertension in haemodialysis patients is an unique diagnostic, prognostic and therapeutic challenge [18]. The main aim of this review is to systematize the current state of knowledge concerning hypertension in haemodialysis patients, especially pathophysiology, variability, measurement methods, target-values of blood pressure, and mode of antihypertensive treatment.

\section{Pathophysiology of hypertension in haemodialysis patients}

The pathogenesis of hypertension in ESKD patients include increased extracellular volume, increased sympathetic and renin-angiotensin-aldosterone (RAA) systems activity, secondary hyperparathyroidism, endothelial cell dysfunction, increased oxidative stress and exposure to erythropoiesis-stimulating agents (ESAs) [19] (Table I).

Volume overload is the main factor participating in the pathogenesis of arterial hypertension in dialysis patients [20,21]. The inability to excrete sodium and water via failured kidney contributes to increased extracellular volume, increased cardiac output and, as a consequence, increased blood pressure in haemodialysis patients.

The inadequate activity of RAA system has long been implicated in the etiology of hypertension in haemodialysis patients [19]. In a study of 51 haemodialysis patients, there were significant differences in the plasma renin activity (PRA) between normotensive subjects $(\mathrm{n}=9)$, hypertensive subjects whose blood pressure was controlled by ultrafiltration and dietary sodium restriction $(n=24)$, and subjects with persistent hypertension $(n=18)$ [22]. PRA was the lowest in the normotensive group, significantly higher in the group with controlled hypertension, and

Table I. Causes of hypertension in haemodialysis patients with chronic kidney disease

\begin{tabular}{|l|}
\hline $\begin{array}{l}\text { Causes of hypertension in haemodialysis patients with chronic } \\
\text { kidney disease }\end{array}$ \\
\hline Increased extracellular volume - volume overload \\
\hline Increased sympathetic nervous system activity \\
\hline Increased renin-angiotensin-aldosterone system activity \\
\hline High salt diet \\
\hline Secondary hyperparathyroidism \\
\hline Endothelial cell dysfunction \\
\hline Increased oxidative stress \\
\hline Exposure to erythropoiesis — stimulating agents (ESAs) \\
\hline
\end{tabular}


the highest in the persistently hypertensive group. In 17 out of 18 persistently hypertensive subjects, bilateral nephrectomy resulted in significant reductions in blood pressure. Post-nephrectomy PRA was measured in 12 subjects, and was significantly lower, suggesting that elevated baseline PRA may have contributed to the poorly controlled hypertension. Angiotensin II and aldosterone which are primary mediators of RAA system, both contribute to left ventricular hypertrophy (LVH) and endothelial cell dysfunction independently of blood pressure [19].

Patients with ESKD are characterized by higher sympathetic nervous system (SNS) activity (measured by skeletal muscle sympathetic nerve activity [MSNA]), mean arterial blood pressure, and vascular resistance than healthy controls, or CKD stage 5 patients who have had bilateral nephrectomy [23]. Furthermore, in renal transplant recipients, MSNA remained elevated following renal transplantation, but subsequently decreased following native kidneys nephrectomy. It suggests that it is not uraemia per se, but rather signaling from diseased kidneys that results in elevated MSNA and hypertension. However, while the initial trigger for increased SNS activity is likely renal ischaemia with a consequential increase of renal afferent nerve activation, other mediators that are also affected by CKD stage 5 such as nitric oxide, angiotensin II, and superoxide and may further modify blood pressure. Nocturnal decrease of blood pressure is frequently absent in patients with CKD and it is associated with adverse outcomes [24]. There is evidence that more frequent haemodialysis sessions, whether through increased removal of uremic toxins or improvement of volume status, may lower SNS activity. In a study of stable non-diabetic haemodialysis patients whose blood pressure was controlled with or without antihypertensive drugs, conversion from standard three times a week $(12 \mathrm{~h} /$ week total HD time) to haemodialysis six times a week (12h/ /week total HD time) resulted in significant reduction in ambulatory blood pressure (systolic and diastolic) and MSNA. The subjects who had studies repeated following conversion back to standard haemodialysis regimen demonstrated an increase in MSNA back to baseline values [25].

The secondary hyperparathyroidism that accompanies CKD may contribute to the high prevalence of hypertension in these patients. The evidence based on a retrospective study in CKD patients demonstrating that systolic and diastolic blood pressure were significantly increased in subjects with increased plasma concentration of parathyroid hormone (PTH) [26]. Furthermore, a possible mechanism was suggested by the findings of increased platelet cytosolic calcium in the group with increased PTH plasma concentration. Mean blood pressure correlated highly significant with cytosolic calcium and plasma PTH concentration. Treatment with active vitamin D (alfacalcidol) significantly lowered plasma PTH level, and mean blood pressure. Kuczera et al. observed a decrease of blood pressure in haemodialysis patients with chronic kidney disease and secondary hyperparathyroidism treated with calcimimetic cinacalcet [27]. These observations were confirmed recently in the analysis of the results from EVOLVE study [28].

Erythropoiesis-stimulating agents used to correct the anaemia associated with CKD may also lead to blood pressure increase [29]. The proposed mechanisms specific to haemodialysis patients include increase of ET-1 release and increased sensitivity to angiotensin II and adrenergic stimuli. The effect of blood pressure is dependent on the dose, but not necessary the pre-treatment blood pressure as both previously normotensive and hypertensive patients can have ESAs related blood pressure increase [19].

\section{Blood pressure variability among haemodialysis patients}

In the majority of HD patients (85\%) decrease of blood pressure during haemodialysis procedures is observed [30]. Agarwal et al. observed that home BP increases over time after haemodialysis treatment and this relationship was non-linear and reach plateau after approximately 2 days. It is important to stress that probing dry-weight does not perturb the time-dependent relationship of home BP but steepens the slope for ambulatory BP. Increase in interdialytic weight gain reduces the intercept BP but steepens the slope of BP changes. Furthermore, the timing of home BP monitoring influences the accuracy and precision of the measurements and the time elapsed after dialysis must to be considered in interpreting the home BP recordings in haemodialysis patients [31]. Taking into account facts mentioned above, it should be stated that blood pressure in haemodialysis patients is characterized by high variability. In fact, variability in blood pressure within patients is similar to that between patients [32].

The percentage of interdialytic weight gain (overall weight gain/estimated dry weight x 100) predicts increased pre-HD systolic blood pressure and greater reduction in systolic blood pressure from pre- to post-HD, particularly in non-diabetics, younger patients, and those with greater estimated dry weight [33]. In one large, observational study, increased interdialytic weight gain (IDWG) was associated with increased mortality [34]. 
In the minority of HD patients (15\%) blood pressure increases during haemodialysis [30]. The main cause of blood pressure increase in these patients is the increase of vascular resistance. Using cardiac output estimated from echocardiograms and blood pressure measurements before and after haemodialysis, it was found there was a significant increase in vascular resistance from pre- to post-haemodialysis in the intradialytic hypertension patients compared to patients whose blood pressure did not increase during haemodialysis. There were no significant differences in the change in cardiac output (or in the individual pre- or post-dialysis measurements) between the 2 groups. These authors and others have sought to identify specific mediators of the increase in blood pressure that may be related to over secretion of endogenous vasoconstrictive substances. In the study by Chou et al. [35], there was no evidence that surges in sympathetic nervous system activity (assessed using plasma catecholamines) or in RAA system activity (assessed using plasma renin activity) could explain such an increase in vascular resistance. They did find, however, imbalances in endothelial cell-derived mediators after dialysis in the intradialytic hypertension patients. Specifically, there were higher plasma concentration of the vasoconstrictor - endothelin-1 (ET-1) and lower concentration ratios of the vasodilator nitric oxide to ET-1. Other studies have investigated changes in ET-1 during dialysis in intradialytic hypertension and found suggestive, but not confirmatory evidence, to support this hypothesis. Raj et al. [36] found decreases in ET-1 in hypotension-prone patients with a trend toward increases in ET-1 in the intradialytic hypertension group. El-Shafey et al. [37] found increased plasma ET-1 concentration in intradialytic hypertension patients. Based on the evidence that vasoconstriction may be a predominant mechanism for intradialytic hypertension and that ET-1 has been implicated as a causative mediator for this, further investigation has to be directed toward the overall role of endothelial cell dysfunction in intradialytic hypertension. It was found that patients with intradialytic hypertension had lower flow-mediated vasodilation [38]. This assessment of endothelial cell function occurred on a non-haemodialysis day so it was not influenced by the haemodialysis procedure. The intradialytic hypertension patients also had lower number of circulating endothelial progenitor cells than the controls. It is suggested that circulating endothelial progenitor cells number is a marker of cardiovascular risk (lower number indicates higher risk) [39]. These were measured prior to dialysis, so that they also were not influenced by the haemodialysis procedure. It is of note that in the Inrig et al. study [38], the change of plasma ET-1 concentration from pre- to post-haemodialysis was not different between the intradialytic hypertension patients and haemodialysis controls. So, while endothelial cell dysfunction appears to be more pronounced in intradialytic hypertension patients, the most recent research has focused on specific mechanisms, by which the endothelial cells influence intradialytic blood pressure [40].

\section{How to measure blood pressure in chronic kidney disease patients on haemodialysis?}

Among the features of the ideal method of measuring blood pressure simplicity and low cost, reliable diagnosis of hypertension, prognostic value in assessing the risk of organ damage and prognostic significance should be listed. There are several methods of blood pressure measurement in haemodialysis patients with chronic kidney disease: automatic 44-hour recording of blood pressure (Ambulatory BP Monitoring - ABPM), not standardized measurements done before and after haemodialysis, standardized measurements done before and after haemodialysis (Dialysis Unit Blood Pressures) and individual measurements (at home) performed between haemodialysis procedures (Home BP Monitoring) (Table II). The identification and treatment of hypertension in CKD has to face peculiar problems because of the marked alterations in 24-hour blood pressure (BP) profile, in particular of a reduced BP dipping at night, and the high prevalence of specific hypertension phenotypes, such as white coat hypertension (WCH), masked hypertension $(\mathrm{MH})$ [41], hypertension caused by fear of haemodialysis or of puncture a needle.

Taking into account already discussed high blood pressure variability in haemodialysis patients, the automatic 44-hour recording of blood pressure (ABPM) is a "gold standard" among methods of measuring blood pressure in haemodialysis patients with chronic kidney disease. ABPM extended to 44-hour in comparison to 24-hour covers the whole mid-week dialysis interval [18]. This method is also

Table II. Methods of blood pressure measurement in haemodialysis patients

\begin{tabular}{|l|}
\hline Methods of measuring blood pressure in haemodialysis patients: \\
\hline Home blood pressure monitoring - HBPM \\
\hline Automatic 44-hour recording blood pressure - Ambulatory BP \\
Monitoring \\
\hline $\begin{array}{l}\text { Measurements done before and after haemodialysis — Dialysis Unit } \\
\text { Blood Pressure }\end{array}$ \\
\hline
\end{tabular}


helpful in identifying patients without physiological nocturnal decrease of blood pressure (dipping pattern) and has a prognostic value in assessing the risk of left ventricular hypertrophy [42]. Unfortunately, it is expensive and its acceptance by the patients is low.

Another method of blood pressure monitoring is non-standardized measurements done before and after haemodialysis. It is a routine clinical practice characterized by low cost and great simplicity. However, a low consistence between not standardized monitoring of blood pressure and automatic 44-hour recording of blood pressure is observed [43]. Agarwal et al. reported a $13.5 \mathrm{mmHg}$ increase of systolic blood pressure in the measurement performed directly before haemodialysis [43]. Blood pressure measured before and after dialysis does not correlate well with those recorded outside the dialysis unit [44]. $\mathrm{BP}$ assessed before and after dialysis, even if obtained using standardized methods, correlates poorly with interdialytic ambulatory BP [43, 45]. Khangura et al. reported that blood pressure measured before haemodialysis had no significant prognostic value for risk of left ventricular hypertrophy [47]. In contrast, BP assessed outside the dialysis unit, whether obtained by interdialytic automatic BP measurement, or self-measured BP at home is useful in diagnosing left ventricular hypertrophy [42]. Thus, dialysis unit measurement is only distantly related to ambulatory BP, or target organ damage. This poor relationship calls into question the use of BP obtained before and after dialysis for the diagnosis and treatment of hypertension among patients on haemodialysis [46].

Among the methods used in dialysis unit it is also possible to do standardized measurements before and after haemodialysis. In this method the blood pressure is measured in a quiet and warm room, after 5 minutes of rest. Then, the arithmetic average of three consecutive measurements (taken every few minutes) should be calculated. Although this method is also characterized by great simplicity, to use it in everyday clinical practice in dialysis units would require multiplying the number of employees and thus would significantly increase the cost. However, standardized measurements taken after haemodialysis are more consistent with automatic 44-hour recording of blood pressure than not standardized measurements taken before and after haemodialysis [42].

The last method used for the assessment for blood pressure among haemodialysis patients is home blood pressure monitoring - HBPM. This method is also characterized by low cost and great simplicity but patients have to be instructed in the appropriate usage of this method of measurement. Self-inflating automatic and semi-automatic oscillometric devices with shoulder cuff are recommended. Only the devices with proven accuracy should be used and patients should be advised to write down the measurements [48]. The measurements should be taken twice a day on days without haemodialysis. Every time the blood pressure measurements should be performed in a quiet room, with the patient in seated position, back and arm supported, after 5 minutes of rest and with two measurements per occasion taken 1-2 minutes apart [18]. Then, the arithmetic average of measurements from several days should be calculated [48, 49]. Among the advantages of this method low cost and great simplicity, as well as the ability to reliably identify hypertension and prognostic value of the risk of organ complications should be mentioned. Individual measurements (home BP monitoring) taken between haemodialysis have a prognostic value in assessing the risk of target organ damage and prognostic significance [42]. They are also characterized by high sensitivity $(-80 \%)$ and high specificity $(-84 \%)$ in the diagnosis of hypertension [45]. Thus, the diagnosis and treatment of hypertension should be primarily guided by the results of the home blood pressure monitoring performed between haemodialysis sessions.

\section{Diagnosis of hypertension and target-values of blood pressure in haemodialysis patients}

There are number of published guidelines (e.g. the guidelines of European Society of Hypertension [48] or Polish Society of Hypertension [49]) that can be used in the clinical practice for blood pressure control in the non-dialysis-dependent CKD population. However, there are no clearly defined guidelines for hypertensive patients in the haemodialysis population [50-52].

Hypertension in haemodialysis patients should be defined on the basis of home BP or ABPM measurements. Thresholds and methods are defined by the ASH/ASN (American Society of Hypertension/ /American Society of Nephrology) [53], the EURECA-m (European Renal and Cardiovascular Medicine) working group of ERA-EDTA (The European Renal Association - European Dialysis and Transplant Association) [54] and the relevant ESH (European Society of Hypertension) Guidelines [55-57]. According to these recommendations hypertension in haemodialysis patients should be diagnosed on the basis of HBPM if an average $\mathrm{BP} \geq 135 / 85 \mathrm{mmHg}$ for measurements done in the morning and in the evening over 6 non-dialysis days (covering a period 
of 2 weeks) is observed [48, 49, 18]. Hypertension in $\mathrm{HD}$ patients should be also defined on the basis of ABPM if an average BP $\geq 130 / 80 \mathrm{mmHg}$ over 44-hour monitoring, covering the whole mid-week dialysis interval, is observed $[42,18]$. For haemodialysis patients no recommendations can be made on the basis of pre- or post-dialysis BP [18].

The thresholds for blood pressure targets in CKD patients treated with haemodialysis are still matter of debates. Agarwal et al. (2010) reported that the lowest risk of death is found in patients with HBPM SBP 120-130 mmHg [58]. Therefore it might be concluded that the target systolic blood pressure measured between haemodialysis sessions (HBPM) seems to be similar to general population, this means $<135 \mathrm{mmHg}[48,41]$.

\section{Antihypertensive treatment in patients with chronic kidney disease on haemodialysis}

Treatment methods of hypertension can be divided into three groups: non-pharmacological, pharmacological and invasive/surgical. Among the non-pharmacological methods of antihypertensive treatment in patients with chronic kidney disease on haemodialysis reducing volaemia, reducing sodium intake from dialysate or in the diet, should be listed. Reducing volaemia can be achieved in two ways. First, by reducing dry weight, what can be done by haemodialysis with increased ultrafiltration. Secondly, by reducing sodium intake, attained both by reducing the concentration of sodium in the dialysate and the use of a low sodium diet. Non-pharmacological interventions targeting sodium and volume excess are fundamental for BP reduction in this population and should be carefully implemented before pharmacological interventions [18].

\section{Non-pharmacological methods — reducing volaemia}

Conceptually, slow reduction in estimated dry weight over time with little change in interdialytic weight gain could lower blood pressure without imposing excessive dietary restrictions on patients. Gradual dry weight reduction leads to the improved ambulatory blood pressure in hypertensive haemodialysis patients [59]. Techniques that monitor blood volume during haemodialysis may offer opportunity to better estimate dry weight in haemodialysis patients. The relation between dry-weight reduction and hypertension is well described in a randomized trial DRIP (Dry-Weight Reduction in Hypertensive Hae- modialysis Patients) [59]. In this study standard ultrafiltration and additional ultrafiltration $0.1 \mathrm{~kg} / 10 \mathrm{~kg}$ of weight were compared in 150 haemodialysis patients with hypertension during the eight-week follow-up. As a consequence, respectively weight loss of $1 \mathrm{~kg}$ and no decrease in body weight were observed. The weight loss of $1 \mathrm{~kg}$ was related to lowering blood pressure of $7 / 3 \mathrm{mmHg}$ [59]. On the other hand, in another study looking at the potential long-term effects of volume status, as assessed by relative plasma slope (flatter indicating volume overload) during haemodialysis treatment, it was showed that volume overload was associated with increased mortality independently on ultrafiltration rate [59-63].

Another non-pharmacological method of antihypertensive treatment in haemodialysis patients is the reducing sodium intake achieved by reduction of sodium concentration in dialysate. Movilli et al. found a positive sodium balance during haemodialysis procedure in $72 \%$ haemodialysis patients with chronic kidney disease [64]. Relatively high dialysate sodium concentration (with sodium concentration equal $140 \mathrm{mmol} / \mathrm{l}$ ) causes decreased sodium removal, which leads to volume overload and then to hypertension. Moreover, use of high sodium concentration in the dialysate results in the increase of serum sodium concentration, which leads to increased thirst and, as a consequence, to the volume overload and finally to hypertension [65]. De Paula et al. observed decreases of blood pressure due to individualization of sodium concentration in dialysate, equal to that found before 3 previous haemodialysis procedures [66].

Another method of reducing sodium intake is based on low sodium diet. Magden et al. found SBP decrease from $147 \mathrm{mmHg}$ to $119 \mathrm{mmHg}$ in 15 haemodialysis patients with chronic kidney disease using low sodium diet [67]. Moreover, Maduell et al. reported the decrease of blood pressure from 139/ $179 \mathrm{mmHg}$ to $132 / 75 \mathrm{mmHg}$ in 15 haemodialysis patients with chronic kidney disease in response to salt reduction from $10.2 \mathrm{~g}$ to $7.1 \mathrm{~g}$ per day [68]. Current daily intake of salt in Poland is around $14.2 \mathrm{~g}$, which is three times more than the WHO recommendation amounting to 5-6 g per day. Many sources of sodium in the diet could be mentioned. Sodium is a natural component of animal food products, component of salt used for seasoning meals and addition to processed food (which is about $85 \%$ of sodium intake). Among food with extremely high sodium content, is instant soup $(1.9 \mathrm{~g}-$ i.e. $2.4 \mathrm{~g}$ of salt in one portion), instant noodle soup ( $2.8 \mathrm{~g}$ - i.e. $4.1 \mathrm{~g}$ of salt/ /portion), pizza ( $7 \mathrm{~g}$ - i.e. $12.8 \mathrm{~g}$ of salt), Chinese food (5.5 g-i.e. $11 \mathrm{~g}$ of salt), Indian food ( $3.6 \mathrm{~g}$ i.e. $6.1 \mathrm{~g}$ of salt), kebab ( $4 \mathrm{~g}-$ i.e. $8.4 \mathrm{~g}$ of salt) and 
fast food. Meal in fast food restaurants are composed by sandwich, fries and sauce consists of $4.5 \mathrm{~g}$ of salt which represents $90 \%$ of the daily recommended salt intake [69-71]. Daily sodium intake in haemodialysis patients should be limited to $65 \mathrm{mmol}$ (i.e. $1.5 \mathrm{~g}$ of sodium or $4 \mathrm{~g}$ of sodium chloride) [18]. To achieve this, it is advisable to discontinue the use of salt as a seasoning of meals, preparing dishes with natural and fresh products and avoiding processed food [69-71].

\section{Renal denervation}

Renal denervation is the interventional method currently recommended in selected patients with resistant hypertension. Schlaich et al. in preliminary study described 9 haemodialysis patients with CKD treated by this method using Simplicity catheter. In this study, decrease of systolic blood pressure from $171 \mathrm{mmHg}$ to $138 \mathrm{mmHg}$ was identified 12 months after the renal denervation procedures [72]. Additionally, Hoye et al. described 9 dialysis patients (6 treated by haemodialysis, 3 by peritoneal dialysis) with chronic kidney disease and resistant hypertension treated with EnligHTNTM catheter. In this study, decrease of systolic blood pressure from $179 \mathrm{mmHg}$ to $154 \mathrm{mmHg}$ and decrease of SBP in ABPM from $173 \mathrm{mmHg}$ to $152 \mathrm{mmHg}$ were observed 12 months after renal denervation procedures [73]. To define the role of renal denervation in the hypertension treatment among haemodialysis patients further studies with sham procedures, higher number of participants and longer follow-ups are needed.

\section{Pharmacotherapy}

Two meta-analysis suggest that antihypertensive therapy (including $\beta$-adrenergic antagonists, angiotensin converting enzyme inhibitors [ACEIs], angiotensin II receptor blockers [ARBs], calcium channel blockers [CCBs] and mineralocorticoid receptor antagonists [MRAs]) positively influenced on the prognosis in the haemodialysis patients. The major finding of meta-analysis performed by Agarwal et al. [74] is that the overall benefit of antihypertensive therapy compared with the control (or placebo) group reduced the combined hazard ratio for cardiovascular events by $31 \%$ using a fixed-effects model and by $38 \%$ using a random-effects model. There was substantial heterogeneity between studies with respect to outcomes. However, when studies were divided based on inclusion of normotensive subjects in the randomized group, it explained most of between-study variance. Heterogeneity between normotensive and hypertensive groups was highly significant $(\mathrm{p}=0.006)$. Although the hypertensive group had a pooled hazard ratio of 0.49 (95\% CI: 0.35 to 0.67$)$, the normotensive group had a pooled hazard ratio of 0.86 (95\% CI: 0.67 to 1.12). In fact, even all-cause mortality, an outcome most commonly measured in the observational studies, was not increased with treatment. While, in a meta-analysis by Heerspink et al. [75] it was shown that treatment with agents that lower blood pressure reduces cardiovascular morbidity and mortality in patients on maintenance dialysis. The effects are consistent with or without the presence of hypertension and other comorbidities and across a range of drug classes. Furthermore, this analysis is not able to separate out the effects of blood pressure lowering for specific drug classes. The results do not show any differences in cardiovascular events caused by different drug classes. The data suggest that drugs inhibing renin-angiotensin-system activity, $\beta$-adrenergic antagonists, and calcium-channel blockers are all suitable for use in patients on dialysis

The selection of appropriate antihypertensive pharmacotherapy in haemodialysis patients is still matter of debate. Some arguments in this debate come from the results of HDPAL study [76]. The purpose of HDPAL - randomized, controlled trial was to determine among maintenance haemodialysis patients with left ventricular hypertrophy assessed by echocardiography and hypertension, whether $\beta$-adrenergic antagonists-based antihypertensive therapy was more effective than angiotensin converting enzyme-inhibitor-based antihypertensive therapy in causing a greater regression of left ventricular hypertrophy. In this study subjects were randomly assigned to either open label lisinopril $(n=100)$ or atenolol $(n=100)$, each administered three times per week after dialysis. Monthly monitored home blood pressure (BP) was controlled to $<140 / 90 \mathrm{mmHg}$ with dry weight adjustment and sodium restriction. If the blood pressure target was not achieved calcium channel blockers and subsequently doxazosin, minoxidil and guanfacine were added. The primary outcome was the change in left ventricular mass index (LVMI) from baseline, to 12 months. Among hypertensive patients with left ventricular hypertrophy on maintenance haemodialysis, in the HDPAL trial, treatment based on either atenolol or lisinopril produced statistically and clinically significant reductions in BP from baseline that was sustained over the 12-month course of the trial. Despite a greater reduction in dry weight, compared with atenolol, the administration of lisinopril was associated with an increased risk of hospitalizations for congestive heart failure. In addition, lisinopril therapy was associated with an increased 
risk of all-cause hospitalizations and cardiovascular morbidity. Specifically, lisinopril administration was also associated with an increased incidence of the combined risk of hospitalizations due to congestive heart failure, myocardial infarction, strokes and cardiovascular death. Furthermore, this therapy was also associated with an increased risk of hyperkalemia and emergent treatment for hypertensive crises. It seems then HDPAL trial shows that atenolol-based antihypertensive therapy is superior compared with lisinopril-based therapy in haemodialysis patients. Despite both groups being targeted to home BP of $<140$ / $190 \mathrm{mmHg}$ at each monthly visit, the lisinopril-based group required a statistically greater number of antihypertensive drugs and a greater need for lowering dry weight to lower BP. Moreover, in the lisinopril group, BP lowering remained numerically less using ambulatory BP monitoring and statistically less when assessed by home BP monitoring. Atenolol-based therapy may therefore have conferred cardiovascular protection by improving BP control. The conclusion from this study is that an initial strategy using atenolol ( $\beta$-adrenergic antagonist therapy) is superior to ACE-inhibitor-based therapy, among haemodialysis patients with hypertension and left ventricular hypertrophy. In another study, Cice et al. observed that carvedilol reduces mortality compared with placebo in HD patients with dilated cardiomyopathy [77].

What is interesting, in haemodialysis patients not only typical antihypertensive drugs could reduce blood pressure. Kuczera et al. [27] observed the decrease of blood pressure in 58 haemodialysis patients with chronic kidney disease and secondary hyperparathyroidism treated with calcimimetic cinacalcet. Decrease an average of $7 \mathrm{mmHg}$ of systolic blood pressure and an average of $2 \mathrm{mmHg}$ of diastolic blood pressure after 6 months of cinacalcet therapy was described. These observations was recently confirmed by the analysis of results from the EVOLVE study [28].

\section{Conclusions}

- Patients with chronic kidney disease treated with haemodialysis are characterized by higher prevalence of hypertension and higher variability in blood pressure than the general population. The main reasons for this variability are changes in volaemia.

- In the diagnosis and treatment of hypertension in haemodialysis patients with chronic kidney disease self-measured blood pressure at home done between haemodialysis sessions should be considered.
- Self-measured systolic blood pressure between 120 to $130 \mathrm{mmHg}$ is associated with the best prognosis in haemodialysis patients with chronic kidney disease.

- Reduction of the volaemia by increasing ultrafiltration during haemodialysis procedures, individualization of sodium concentration in the dialysis fluid and low sodium diet are the most important methods in the treatment of hypertension in haemodialysis patients with chronic kidney disease.

- The use of antihypertensive pharmacotherapy in haemodialysis patients with chronic kidney disease reduces mortality in this group of patients.

- The drugs of first-line in hypertension treatment in haemodialysis patients with chronic kidney disease seem to be $\beta$-adrenergic antagonists.

\section{References}

1. Coresh J, Wei GL, McQuillan G, et al. Prevalence of high blood pressure and elevated serum creatinine level in the United States: findings from the third National Health and Nutrition Examination Survey (1988-1994). Arch Intern Med. 2001; 161(9): 1207-1216, indexed in Pubmed: 11343443.

2. Agarwal R, Nissenson AR, Batlle D, et al. Prevalence, treatment, and control of hypertension in chronic hemodialysis patients in the United States. Am J Med. 2003; 115(4): 291-297, doi: 10.1016/ s0002-9343(03)00366-8, indexed in Pubmed: 12967694.

3. Santos SFF, Peixoto AJ. Hypertension in dialysis. Curr Opin Nephrol Hypertens. 2005; 14(2): 111-118, doi: 10.1097/00041552200503000-00005, indexed in Pubmed: 15687836.

4. Hörl MP, Hörl WH. Hemodialysis-associated hypertension: pathophysiology and therapy. Am J Kidney Dis. 2002; 39(2): 227-244, doi: 10.1053/ajkd.2002.30542, indexed in Pubmed: 11840363.

5. Vertes V, Cangiano JL, Berman LB, et al. Hypertension in end-stage renal disease. N Engl J Med. 1969; 280(18): 978-981, doi: 10.1056/ NEJM196905012801802, indexed in Pubmed: 5781668.

6. Hyman DJ, Pavlik VN. Characteristics of patients with uncontrolled hypertension in the United States. N Engl J Med. 2001; 345(7): 479486, doi: 10.1056/NEJMoa010273, indexed in Pubmed: 11519501.

7. Coresh J, Wei GL, McQuillan G, et al. Prevalence of high blood pressure and elevated serum creatinine level in the United States: findings from the third National Health and Nutrition Examination Survey (1988-1994). Arch Intern Med. 2001; 161(9): 1207-1216, doi: 10.1001/archinte.161.9.1207, indexed in Pubmed: 11343443.

8. Foley RN, Herzog CA, Collins AJ, et al. United States Renal Data System. Blood pressure and long-term mortality in United States hemodialysis patients: USRDS Waves 3 and 4 Study. Kidney Int. 2002; 62(5): 1784-1790, doi: 10.1046/j.1523-1755.2002.00636.x, indexed in Pubmed: 12371980.

9. Salem MM. Hypertension in the hemodialysis population: a survey of 649 patients. Am J Kidney Dis. 1995; 26(3): 461-468, doi: 10.1016/0272-6386(95)90492-1, indexed in Pubmed: 7645554.

10. Rocco MV, Yan G, Heyka RJ, et al. HEMO Study Group. Risk factors for hypertension in chronic hemodialysis patients: baseline data from the HEMO study. Am J Nephrol. 2001; 21(4): 280-288, doi: 46262, indexed in Pubmed: 11509799.

11. Collins AJ, Foley RN, Herzog C, et al. Excerpts from the US Renal Data System 2009 Annual Data Report. Am J Kidney Dis. 2010; 55(1 Suppl 1): S1-420, A6, doi: 10.1053/j.ajkd.2009.10.009, indexed in Pubmed: 20082919.

12. Braun J, Oldendorf M, Moshage W, et al. Electron beam computed tomography in the evaluation of cardiac calcification in chronic dialysis patients. Am J Kidney Dis. 1996; 27(3): 394-401, indexed in Pubmed: 8604709. 
13. Moe SM. Pathophysiology of vascular calcification in chronic kidney disease. Circulation Research. 2004; 95(6): 560-567, doi: 10.1161/01.res.0000141775.67189.98.

14. London GM. Cardiovascular disease in chronic renal failure: pathophysiologic aspects. Semin Dial. 2003; 16(2): 85-94, indexed in Pubmed: 12641870.

15. Stewart GA, Gansevoort RT, Mark PB, et al. Electrocardiographic abnormalities and uremic cardiomyopathy. Kidney Int. 2005; 67(1): 217-226, doi: 10.1111/j.1523-1755.2005.00072.x, indexed in Pubmed: 15610245

16. Paoletti E, Specchia C, Di Maio G, et al. The worsening of left ventricular hypertrophy is the strongest predictor of sudden cardiac death in haemodialysis patients: a 10 year survey. Nephrol Dial Transplant. 2004; 19(7): 1829-1834, doi: 10.1093/ndt/gfh288, indexed in Pubmed: 15128888.

17. Choi H, Kim M, Kim H, et al. Excess mortality among patients on dialysis: Comparison with the general population in Korea. Kidney Res Clin Pract. 2014; 33(2): 89-94, doi: 10.1016/j.krcp.2014.04.001, indexed in Pubmed: 26877956.

18. Sarafidis PA, Persu A, Agarwal R, et al. Hypertension in dialysis patients: a consensus document by the European Renal and Cardiovascular Medicine (EURECA-m) working group of the European Renal Association-European Dialysis and Transplant Association (ERA-EDTA) and the Hypertension and the Kidney working group of the European Society of Hypertension (ESH). Nephrol Dial Transplant. 2017; 32(4): 620-640, doi: 10.1093/ndt/gfw433, indexed in Pubmed: 28340239.

19. Van Buren PN, Inrig JK. Hypertension and hemodialysis: pathophysiology and outcomes in adult and pediatric populations. Pediatr Nephrol. 2012; 27(3): 339-350, doi: 10.1007/s00467-011-17753, indexed in Pubmed: 21286758.

20. Santi Xavier P, Perez Vogt B, Cuadrado Martin L, et al. Total body water and failure to control blood pressure by medication in hemodialysis patients. Nephron Extra. 2014; 4(2): 95-100, doi: 10.1159/000363322, indexed in Pubmed: 25177337.

21. Hörl MP, Hörl WH. Hemodialysis-associated hypertension: pathophysiology and therapy. Am J Kidney Dis. 2002; 39(2): 227-244, doi: 10.1053/ajkd.2002.30542, indexed in Pubmed: 11840363.

22. Weidmann P, Maxwell MH, Lupu AN, et al. Plasma renin activity and blood pressure in terminal renal failure. N Engl J Med. 1971; 285(14): 757-762, doi: 10.1056/NEJM197109302851401, indexed in Pubmed: 5567260.

23. Converse RL, Jacobsen TN, Toto RD, et al. Sympathetic overactivity in patients with chronic renal failure. $\mathrm{N}$ Engl J Med. 1992; 327(27): 1912-1918, doi: 10.1056/NEJM199212313272704, indexed in Pubmed: 1454086.

24. Liu M, Takahashi H, Morita Y, et al. Non-dipping is a potent predictor of cardiovascular mortality and is associated with autonomic dysfunction in haemodialysis patients. Nephrol Dial Transplant. 2003; 18(3): 563-569, indexed in Pubmed: 12584280.

25. Zilch O, Vos PF, Oey PL, et al. Sympathetic hyperactivity in haemodialysis patients is reduced by short daily haemodialysis. J Hypertens. 2007; 25(6): 1285-1289, doi: 10.1097/HJH.0b013e3280f9df85, indexed in Pubmed: 17563543

26. Raine AE, Bedford L, Simpson AW, et al. Hyperparathyroidism, platelet intracellular free calcium and hypertension in chronic renal failure. Kidney Int. 1993; 43(3): 700-705, doi: 10.1038/ ki.1993.100, indexed in Pubmed: 8455369.

27. Kuczera P, Adamczak M, Wiecek A. Treatment with cinacalcet decreases systolic blood pressure in haemodialysed patients with chronic kidney disease and secondary hyperparathyroidism. Arterial Hypertension. 2015; 19(3): 129-134, doi: 10.5603/ah.2015.0016.

28. Chang TI, Abdalla S, London GM, et al. The effects of cinacalcet on blood pressure, mortality and cardiovascular endpoints in the EVOLVE trial. J Hum Hypertens. 2016; 30(3): 204-209, doi: 10.1038/jhh.2015.56, indexed in Pubmed: 26040438.

29. Eschbach JW, Abdulhadi MH, Browne JK, et al. Recombinant human erythropoietin in anemic patients with end-stage renal disease. Results of a phase III multicenter clinical trial. Ann Intern Med. 1989; 111(12): 992-1000, indexed in Pubmed: 2688507.
30. Agarwal R, Alborzi P, Satyan S, et al. Dry-weight reduction in hypertensive hemodialysis patients (DRIP): a randomized, controlled trial. Hypertension. 2009; 53(3): 500-507, doi: 10.1161/HYPERTENSIONAHA.108.125674, indexed in Pubmed: 19153263.

31. Agarwal R, Light RP. Chronobiology of arterial hypertension in hemodialysis patients: implications for home blood pressure monitoring. Am J Kidney Dis. 2009; 54(4): 693-701, doi: 10.1053/j. ajkd.2009.03.018, indexed in Pubmed: 19515473.

32. Rohrscheib MR, Myers OB, Servilla KS, et al. DCI Medical Directors. Age-related blood pressure patterns and blood pressure variability among hemodialysis patients. Clin J Am Soc Nephrol. 2008; 3(5): 1407-1414, doi: 10.2215/CJN.00110108, indexed in Pubmed: 18701616.

33. Inrig JK, Patel UD, Gillespie BS, et al. Relationship between interdialytic weight gain and blood pressure among prevalent hemodialysis patients. Am J Kidney Dis. 2007; 50(1): 108-18, 118.e1, doi: 10.1053/j.ajkd.2007.04.020, indexed in Pubmed: 17591530.

34. Foley RN, Herzog CA, Collins AJ, et al. United States Renal Data System. Blood pressure and long-term mortality in United States hemodialysis patients: USRDS Waves 3 and 4 Study. Kidney Int. 2002; 62(5): 1784-1790, doi: 10.1046/j.1523-1755.2002.00636.x, indexed in Pubmed: 12371980.

35. Chou KJ, Lee PT, Chen CL, et al. Physiological changes during hemodialysis in patients with intradialysis hypertension. Kidney Int. 2006; 69(10): 1833-1838, doi: 10.1038/sj.ki.5000266, indexed in Pubmed: 16691262

36. Raj DSC, Vincent B, Simpson K, et al. Hemodynamic changes during hemodialysis: role of nitric oxide and endothelin. Kidney Int. 2002; 61(2): 697-704, doi: 10.1046/j.1523-1755.2002.00150.x, indexed in Pubmed: 11849413.

37. El-Shafey EM, El-Nagar GF, Selim MF, et al. Is there a role for endothelin-1 in the hemodynamic changes during hemodialysis? Clin Exp Nephrol. 2008; 12(5): 370-375, doi: 10.1007/s10157008-0065-2, indexed in Pubmed: 18568290.

38. Inrig JK, Van Buren P, Kim C, et al. Intradialytic hypertension and its association with endothelial cell dysfunction. Clin J Am Soc Nephrol. 2011; 6(8): 2016-2024, doi: 10.2215/CJN.11351210, indexed in Pubmed: 21757643.

39. Werner N, Kosiol S, Schiegl T, et al. Circulating endothelial progenitor cells and cardiovascular outcomes. N Engl J Med. 2005; 353(10): 999-1007, doi: 10.1056/NEJMoa043814, indexed in Pubmed: 16148285.

40. Buren PV, Inrig J. Mechanisms and treatment of intradialytic hypertension. Blood Purification. 2016; 41(1-3): 188-193, doi: $10.1159 / 000441313$.

41. Parati G, Ochoa JE, Bilo G, et al. European Renal and Cardiovascular Medicine (EURECA-m) working group of the European Renal Association-European Dialysis Transplantation Association (ERA-EDTA). Hypertension in Chronic Kidney Disease Part 1: Out-of-Office Blood Pressure Monitoring: Methods, Thresholds, and Patterns. Hypertension. 2016; 67(6): 1093-1101, doi: 10.1161/HYPERTENSIONAHA.115.06895, indexed in Pubmed: 27141058.

42. Agarwal R, Brim NJ, Mahenthiran J, et al. Out-of-hemodialysis-unit blood pressure is a superior determinant of left ventricular hypertrophy. Hypertension. 2006; 47(1): 62-68, doi: 10.1161/01. HYP.0000196279.29758.f4, indexed in Pubmed: 16344376.

43. Agarwal R, Lewis RR. Prediction of hypertension in chronic hemodialysis patients. Kidney Int. 2001; 60(5): 1982-1989, doi: 10.1046/j.1523-1755.2001.00997.x, indexed in Pubmed: 11703618.

44. Agarwal R. Blood pressure and mortality among hemodialysis patients. Hypertension. 2010; 55(3): 762-768, doi: 10.1161/ hypertensionaha.109.144899.

45. Agarwal R, Andersen MJ, Bishu K, et al. Home blood pressure monitoring improves the diagnosis of hypertension in hemodialysis patients. Kidney Int. 2006; 69(5): 900-906, doi: 10.1038/ sj.ki.5000145, indexed in Pubmed: 16518349.

46. Agarwal R, Peixoto AJ, Santos SFF, et al. Pre- and postdialysis blood pressures are imprecise estimates of interdialytic ambulatory blood pressure. Clin J Am Soc Nephrol. 2006; 1(3): 389-398, doi: 10.2215/CJN.01891105, indexed in Pubmed: 17699236. 
47. Khangura J, Culleton BF, Manns BJ, et al. Alberta Kidney Disease Network. Association between routine and standardized blood pressure measurements and left ventricular hypertrophy among patients on hemodialysis. BMC Nephrol. 2010; 11: 13, doi: 10.1186/14712369-11-13, indexed in Pubmed: 20576127.

48. Mancia G, Fagard R, Narkiewicz K, et al. 2013 ESH/ESC Guidelines for the management of arterial hypertension. Journal of Hypertension. 2013; 31(7): 1281-1357, doi: 10.1097/01. hjh.0000431740.32696.cc.

49. Tykarski A, Narkiewicz K, Gaciong Z, et al. 2015 guidelines for the management of hypertension. Recommendations of the Polish Society of Hypertension - short version. Kardiol Pol. 2015; 73(8): 676-700, doi: 10.5603/KP.2015.0157, indexed in Pubmed: 26304155.

50. Santos SFF, Mendes RB, Santos CA, et al. Profile of interdialytic blood pressure in hemodialysis patients. Am J Nephrol. 2003; 23(2): 96-105, doi: 10.1159/000068038, indexed in Pubmed: 12481148.

51. Mailloux LU, Haley WE. Hypertension in the ESRD patient: pathophysiology, therapy, outcomes, and future directions. Am J Kidney Dis. 1998; 32(5): 705-719, doi: 10.1016/s0272-6386(98)701465, indexed in Pubmed: 9820438.

52. Levey AS, Beto JA, Coronado BE, et al. Controlling the epidemic of cardiovascular disease in chronic renal disease: what do we know? What do we need to learn? Where do we go from here? National Kidney Foundation Task Force on Cardiovascular Disease. Am J Kidney Dis. 1998; 32(5): 853-906, doi: 10.1016/s0272-6386(98)701453, indexed in Pubmed: 9820460.

53. Agarwal R, Flynn J, Pogue V, et al. Assessment and management of hypertension in patients on dialysis. J Am Soc Nephrol. 2014; 25(8): 1630-1646, doi: 10.1681/ASN.2013060601, indexed in Pubmed: 24700870.

54. Parati G, Ochoa JE, Bilo G, et al. European Renal and Cardiovascular Medicine (EURECA-m) working group of the European Renal Association-European Dialysis Transplantation Association (ERA-EDTA). Hypertension in Chronic Kidney Disease Part 1: Out-of-Office Blood Pressure Monitoring: Methods, Thresholds, and Patterns. Hypertension. 2016; 67(6): 1093-1101, doi: 10.1161/HYPERTENSIONAHA.115.06895, indexed in Pubmed: 27141058.

55. Parati G, Stergiou GS, Asmar R, et al. ESH Working Group on Blood Pressure Monitoring. European Society of Hypertension guidelines for blood pressure monitoring at home: a summary report of the Second International Consensus Conference on Home Blood Pressure Monitoring. J Hypertens. 2008; 26(8): 1505-1526, doi: 10.1097/ HJH.0b013e328308da66, indexed in Pubmed: 18622223.

56. Mancia G, Fagard R, Narkiewicz K, et al. 2013 ESH/ESC Guidelines for the management of arterial hypertension. Journal of Hypertension. 2013; 31(7): 1281-1357, doi: 10.1097/01. hjh.0000431740.32696.cc.

57. Parati G, Stergiou G, O'Brien E, et al. European Society of Hypertension practice guidelines for ambulatory blood pressure monitoring. Journal of Hypertension. 2014; 32(7): 1359-1366, doi: 10.1097/ hjh.0000000000000221.

58. Agarwal R. Blood Pressure and Mortality Among Hemodialysis Patients. Hypertension. 2010; 55(3): 762-768, doi: 10.1161/ hypertensionaha.109.144899.

59. Agarwal R, Alborzi P, Satyan S, et al. Dry-weight reduction in hypertensive hemodialysis patients (DRIP): a randomized, controlled trial. Hypertension. 2009; 53(3): 500-507, doi: 10.1161/HYPERTENSIONAHA.108.125674, indexed in Pubmed: 19153263.

60. Klassen PS, Lowrie EG, Reddan DN, et al. Association between pulse pressure and mortality in patients undergoing maintenance hemodialysis. JAMA. 2002; 287(12): 1548-1555, doi: 10.1001/ jama.287.12.1548, indexed in Pubmed: 11911757.

61. Agarwal R. Hypervolemia is associated with increased mortality among hemodialysis patients. Hypertension. 2010; 56(3): 512-517, doi: 10.1161/HYPERTENSIONAHA.110.154815, indexed in Pubmed: 20625076.

62. Van Stone JC, Bauer J, Carey J. The effect of dialysate sodium concentration on body fluid distribution during hemodialysis. Trans Am Soc Artif Intern Organs. 1980; 26: 383-386, indexed in Pubmed: 7018056.

63. Sarkar SR, Wystrychowski G, Zhu F, et al. Fluid dynamics during hemodialysis in relationship to sodium gradient between dialysate and plasma. ASAIO J. 2007; 53(3): 339-342, doi: 10.1097/ MAT.0b013e318033cba7, indexed in Pubmed: 17515726.

64. Movilli E, Camerini C, Gaggia P, et al. Role of dialysis sodium gradient on intradialytic hypertension: an observational study. Am J Nephrol. 2013; 38(5): 413-419, doi: 10.1159/000355974, indexed in Pubmed: 24216674.

65. Santos SFF, Peixoto AJ. Revisiting the dialysate sodium prescription as a tool for better blood pressure and interdialytic weight gain management in hemodialysis patients. Clin J Am Soc Nephrol. 2008; 3(2): 522-530, doi: 10.2215/CJN.03360807, indexed in Pubmed: 18199846

66. de Paula FM, Peixoto AJ, Pinto LV, et al. Clinical consequences of an individualized dialysate sodium prescription in hemodialysis patients. Kidney Int. 2004; 66(3): 1232-1238, doi: 10.1111/j.15231755.2004.00876.x, indexed in Pubmed: 15327422.

67. Magden K, Hur E, Yildiz G, et al. The effects of strict salt control on blood pressure and cardiac condition in end-stage renal disease: prospective-study. Ren Fail. 2013; 35(10): 1344-1347, doi: 10.3109/0886022X.2013.828259, indexed in Pubmed: 23992461.

68. Maduell F, Navarro V. Dietary salt intake and blood pressure control in haemodialysis patients. Nephrol Dial Transplant. 2000; 15(12): 2063, doi: 10.1093/ndt/15.12.2063, indexed in Pubmed: 11096160.

69. Jeżewska M, et al. The salt contents in selected dinner dry mixes. Bromat Chem Toksyl XLIV. 2011; 3: 585-590.

70. Jaworowska A, Blackham T, Stevenson L, et al. Determination of salt content in hot takeaway meals in the United Kingdom. Appetite. 2012; 59(2): 517-522, doi: 10.1016/j.appet.2012.06.018, indexed in Pubmed: 22772043.

71. Mojska H, Świderska K, Stoś K, et al. Fast foods as a source of salt in children and youth diet. Probl Hig Epidemiol. 2010; 91: 556-559.

72. Schlaich MP, Bart B, Hering D, et al. Feasibility of catheter-based renal nerve ablation and effects on sympathetic nerve activity and blood pressure in patients with end-stage renal disease. Int J Cardiol. 2013; 168(3): 2214-2220, doi: 10.1016/j.ijcard.2013.01.218, indexed in Pubmed: 23453868.

73. Hoye NA, Baldi JC, Jardine DL, et al. Delayed but subtained blood pressure and sympathetic reduction one year after renal denervation in dialysis patients. Nephrol Dial Transpl. ; 2016(suppl. 1): M0054.

74. Agarwal R, Sinha AD. Cardiovascular protection with antihypertensive drugs in dialysis patients: systematic review and meta-analysis. Hypertension. 2009; 53(5): 860-866, doi: 10.1161/HYPERTENSIONAHA.108.128116, indexed in Pubmed: 19273737.

75. Heerspink HJ, Ninomiya T, Zoungas S, et al. Effect of lowering blood pressure on cardiovascular events and mortality in patients on dialysis: a systematic review and meta-analysis of randomised controlled trials. Lancet. 2009; 373(9668): 1009-1015, doi: 10.1016/ S0140-6736(09)60212-9, indexed in Pubmed: 19249092.

76. Agarwal R, Sinha AD, Pappas MK, et al. Hypertension in hemodialysis patients treated with atenolol or lisinopril: a randomized controlled trial. Nephrol Dial Transplant. 2014; 29(3): 672-681, doi: 10.1093/ndt/gft515, indexed in Pubmed: 24398888.

77. Cice G, Ferrara L, D'Andrea A, et al. Carvedilol increases two-year survivalin dialysis patients with dilated cardiomyopathy: a prospective, placebo-controlled trial. J Am Coll Cardiol. 2003; 41(9): 1438-1444, indexed in Pubmed: 12742278. 